\title{
Spatio-temporal distribution of fish larvae in relation to ontogeny and water quality in the oligohaline zone of a North Brazilian estuary
}

\author{
Valérie Sarpedonti ${ }^{1,4}$, Érica Moema Silva da Anunciaçãoº \& Adriana Oliveira Bordalo ${ }^{3}$ \\ ${ }^{1}$ Grupo de Estudos em Ecologia e Desenvolvimento do Ictioplâncton, Instituto de Ciências Biológicas, \\ Universidade Federal do Pará - UFPA, Av. Augusto Corrêa, Guamá, CEP 66075-110, Belém, PA, Brazil \\ ${ }^{2}$ Pós-graduação em Ecologia Aquática e Pesca, Instituto de Ciências Biológicas, Universidade Federal do \\ Pará - UFPA, Cidade Universitária José da Silveira Netto, Av. Augusto Corrêa, 1, Guamá, \\ CEP 66075-110, Belém, PA, Brazil \\ ${ }^{3}$ Laboratório de Hidrocarbonetos, Universidade do Estado do Pará-UEPA, Campus V, Trav., Enéas \\ Pinheiro, 2626, Marco, CEP 66095-100, Belém, PA, Brazil \\ ${ }^{4}$ Corresponding author: Valérie Sarpedonti,e-mail: valerie.sarpedonti@gmail.com
}

SARPEDONTI, V, ANUNCIAÇÃO, E.M.S. \& BORDALO, A.O. Spatio-temporal distribution of fish larvae in relation to ontogeny and water quality in the oligohaline zone of a North Brazilian estuary. Biota Neotrop. (13)3: http://www.biotaneotropica.org.br/v13n3/en/abstract?article+bn01113032013

\begin{abstract}
Larval fish assemblage in Guajará Bay was studied through four quarterly field campaigns and discussed in relation to individuals' development stages and exposure to contaminants poured out by the Pará State Capital City, Belém. Larval densities were low and diversity extremely poor with a strong dominance of clupeids, engraulids and, to a lower extent, sciaenids. The main spawning season was registered at the onset of the rainy period. Pre-flexion and flexion clupeiforms remained in the farmost stations from the city while post-flexion larvae were found near urban activity centres. Unlikely, pre-flexion and flexion sciaenids were scattered along the city waterfront. Post-flexion larvae were rare; it is suggested that sciaenids use the bay as a transitory route between their spawning grounds and more distant nursery grounds. The waters around the city of Belém showed signs of contamination. However, based on the literature, Guajará Bay environmental quality at the time of the study was suitable for fish larvae life. Nitrate with $\mathrm{pH}$ best explained larval distribution.
\end{abstract}

Keywords: Ichthyoplankton, Amazon, urban impact, Belém.

SARPEDONTI, V, ANUNCIAÇÃO, E.M.S. \& BORDALO, A.O. Distribuição espaço-temporal das larvas de peixes em relação à ontogenia e qualidade da água na zona oligohalina de um estuário norte brasileiro. Biota Neotrop. (13)3: http://www.biotaneotropica.org.br/v13n3/pt/abstract?article+bn01113032013

Resumo: O padrão de distribuição das larvas de peixes na Baía do Guajará foi estudado através de coletas trimestrais e discutido em relação aos estágios de desenvolvimento dos indivíduos e a exposição dos mesmos aos contaminantes despejados pela Capital do Estado do Pará, Belém. A densidade e a diversidade larval foram baixas com forte dominância dos clupeídeos, engraulídeos e, em menor grau, os cianídeos. O principal período de reprodução foi definido no início do período chuvoso. Larvas de Clupeiformes em pré-flexão e flexão foram encontradas nos pontos de coletas mais afastados da cidade, enquanto aquelas em pós-flexão prevaleceram nas margens da cidade. Por outro lado, os cianídeos em pré-flexão e flexão foram capturados perto dos centros de atividade urbana, enquando aqueles em pós-flexão foram pouco abundantes. É sugerido que a baía se encontra na rota migratória dos cianídeos entre a área de desova e os berçários mais distantes. Apesar das águas no entorno da cidade de Belém mostraram sinais de contaminação, a qualidade ambiental na Baía do Guajará no momento do estudo estava apropriada para a vida das larvas de peixes. Nitrato com $\mathrm{pH}$ foram as variáveis que melhor explicaram a distribuição larval.

Palavras-chave: Ictioplâncton, Amazônia, impacto urbano, Belém. 


\section{Introduction}

Scientific approaches to assess environmental impacts in water bodies are various; characterization of water quality, use of biomarkers and bioindicators like fish or benthic species, are among the most common practices (http://www.epa.gov/bioiweb1/html/ indicator.html). Fish larvae also allow depiction of anthropogenic disturbances through variations in abundance, distribution and incidence of malformations in embryos or larvae (Schulz \& MartinsJunior 2001, Strand et al. 2004). In all cases, environmental sanity assessment requires baseline values in order to detect eventual alterations. Such data, however, are not always available, especially in emerging countries or vast ecosystems poorly explored such as the Amazon (Weiland et al. 2005, Vinod 2006). As one of many consequences, improper monitoring can prevent sustainable development and implementation of environmental mitigations for the safeguard of environmental resources and human quality of life (Walsh 2000, Maranhão 2011). Such could be the case of the Amazon basin; difficulties of access, large distances, high diversity of habitats or yet lack of professionals turn this region into one of the most complex but undiscovered of the world. Nevertheless, it is also a region passing through a quick expansion of its urban centres, a change that can be viewed as a national welfare improvement but also a threat to the ecological balance (Carvalho 2006, Vinod 2006).

The city of Belém, capital of the State of Pará in Northern Brazil and twelfth largest city of the nation, is situated in Guajará Bay, at the confluence of the Guamá and Maguarí Rivers. Like many other Brazilian metropolises, the city is experiencing both a vertical and horizontal expansion through the construction of high standard condominiums and multiplication of poor districts. In both cases, the lack of urban planning is responsible for a continuous pouring of untreated waste waters into the bay (Ribeiro 2004, Cabral 2007). Recent statistical surveys indicated that in 2011 less than $7 \%$ of the population was benefitted by the urban sanitation network and less than $20 \%$ of the sewage was treated (http://ambientes.ambientebrasil. com.br). As a consequence, the ecosystem is slowly turning into a harmful environment to human beings who use the water to drink, fish, bathe or play (Ribeiro \& Marin 2002). The aquatic life is equally at risk, especially the young stages which, due to their precarious biological system, are more vulnerable to environmental disturbances (Costello \& Gamble 1992, Costello \& Read 1994).

Despite its ecological and social importance, the aquatic environment of Guajará Bay has been poorly monitored and receives little attention. The main objective of this study was to investigate larval fish communities as indicators of ecosystem health status. Larval fish composition and spatio-temporal variations are presented and discussed in relation to larval development stages and environmental aspects. It is hope that this research will establish a baseline for future monitoring of water quality changes along Belem city waterfront.

\section{Material and Methods}

\section{Study area}

The city of Belém, capital of the Pará State, is located at the entrance gate to the Amazon Region, $120 \mathrm{~km}$ away from the Atlantic Ocean. In 2010, the city counted more than 1.3 million of inhabitants scattered in a total area of $1,065 \mathrm{~km}^{2}$. It includes a continental area and 39 islands. Guajará Bay, located at the frontal estuarine zone, between $01^{\circ} 22^{\prime} \mathrm{S}-01^{\circ} 30^{\prime} \mathrm{S}$ parallels and $48^{\circ} 25^{\prime} \mathrm{W}-48^{\circ} 35^{\prime} \mathrm{W}$ meridians, is at the city waterfront; its surface salinity usually varies between 0 and 0.5 , never exceeding 1.5. The Guamá and Maguarí Rivers debouch on the Southern and Northern ends of the bay, respectively (Figure 1). The Western side includes various islands poorly populated and characterized by a very basic urban infrastructure.

Tidal amplitude ranges between $2.3 \mathrm{~m}$ and $3.8 \mathrm{~m}$. Water direction is uniform throughout the water column, going southwards at ebb tide and northwards at flood tide, although a wind-induced northnorthwest current is omnipresent at the water surface (Gregório $\&$ Mendes 2009). Velocity usually does not exceed $2.5 \mathrm{~m} . \mathrm{s}^{-1}$. The deepest areas and stronger currents are encountered at the Onça Island Channel, on the left margin of the Guajará Bay (Figure 1) and at the Guamá River main channel, on the right-hand side of the river bed. In comparison, water currents at the city waterfront are weaker, preventing large dispersion of contaminants poured in the bay (Barros et al. 2011). Further data on the hydrodynamic of the Guajará Bay and Guamá River are available in Barros et al. (2011) and Bezerra et al. (2011).

Seven sampling stations (S1 to S7) were established. Five of them (S2, S3, S4, S6 and S7) were scattered along the city margin, under direct influence of anthropogenic activities (Figure 1). All five were impacted by sewage and domestic wastes poured indiscriminately in the bay. Sources of pollution are as illustrated in Figure 1. The two remaining stations, S1 and S5 were located in areas more distant from the city and free of direct pollution sources.

\section{Field work and laboratory procedures}

Field trips took place in December 2004 (period of climatic transition from 'Dry to Wet' - 'D/W'), March 2005 (Wet season - 'W'), June 2005 (period of climatic transition from 'Wet to Dry' - 'W/D') and September 2005 (Dry season - 'D'). Seasons were set according to the rainfall index presented by Moraes et al. (2005).

Fish larvae were sampled with a conical plankton net of $330 \mu \mathrm{m}$ mesh size positioned at about two meters from the side of the boat. Superficial, horizontal towings were conducted crosscurrent during four minutes after which plankton samples were immediately preserved in neutralized formalin $4 \%$. The volume of water passing through was estimated by a flowmeter placed at the mouth of the net. Three pseudo-replicates were taken per station. All cruises took place during the first quarter moon; stations were always sampled following the same order (from S1 to S7). Water quality at the time and place of larval sampling was assessed through the measurement of nine parameters: Temperature $\left({ }^{\circ} \mathrm{C}\right), \mathrm{pH}$, conductivity $\left(\mathrm{Cnd}-\mu \mathrm{S} . \mathrm{cm}^{-1}\right)$, turbidity $(\mathrm{Tb}-\mathrm{NTU})$, suspended particulate matters (MS $\left.-\mathrm{mg} . \mathrm{l}^{-1}\right)$, chemical oxygen demand $\left(\mathrm{COD}-\mathrm{mg} . \mathrm{l}^{-1}\right)$, orthophosphate $\left(\mathrm{OP}-\mathrm{mg} . \mathrm{1}^{-}\right.$ $\left.{ }^{1}\right)$, nitrate (NTA - mg. $\mathrm{l}^{-1}$ ) and un-ionized ammonia (Ama - mg. $\mathrm{l}^{-1}$ ). Water was sampled from the uppermost water layer and stored in the ice. Analyses were either conducted in situ using a multi-parameter 340 i/SET WTW (WTW Wissenschaftlich-Technische Werkstatten $\mathrm{GmBH}$ ) or by spectro-photometry (HACH DR-2010).

In the laboratory, larvae were sorted under a stereomicroscope, identified to the lowest taxonomic level possible and stored in alcohol $90 \%$. Larval development stage was assessed based on the presence/ absence of the yolk-sac and the flexion of the notochord, defining four groups, namely: yolk-sac larvae, pre-flexion, flexion and postflexion larvae (Moser 1984).

\section{Data analysis}

Densities (number of larvae. $100 \mathrm{~m}^{-3}$ ) were calculated discriminating seasons, stations, families (or species) and development stages. Seasonal variation in fish larval density was tested using the non-parametric two way crossed Analysis of Similarities (ANOSIM) pairwise test with replicates (3) considering the two factors 'season' and 'station'. For this test and the following ones, densities were square-root transformed and standardized prior 
a)

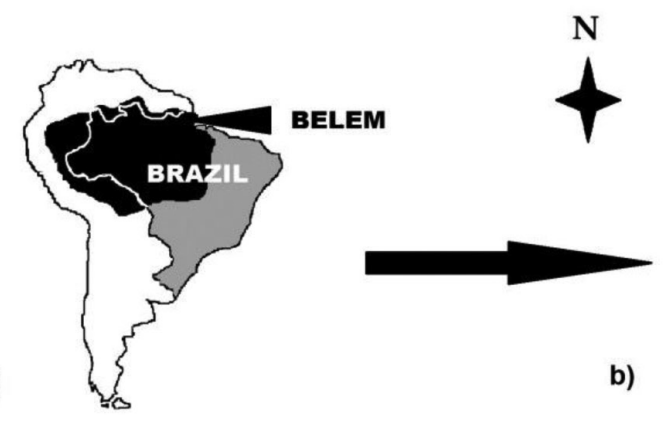

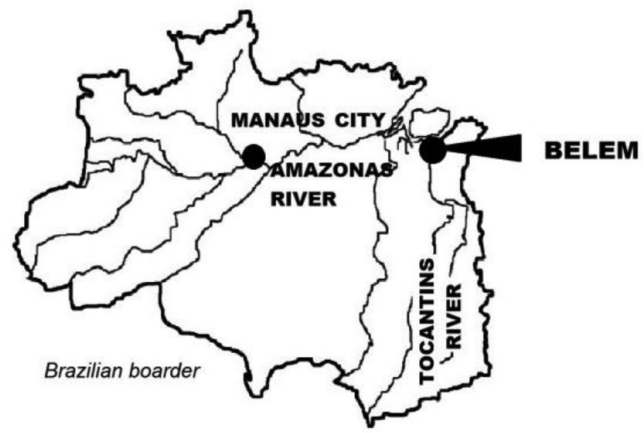
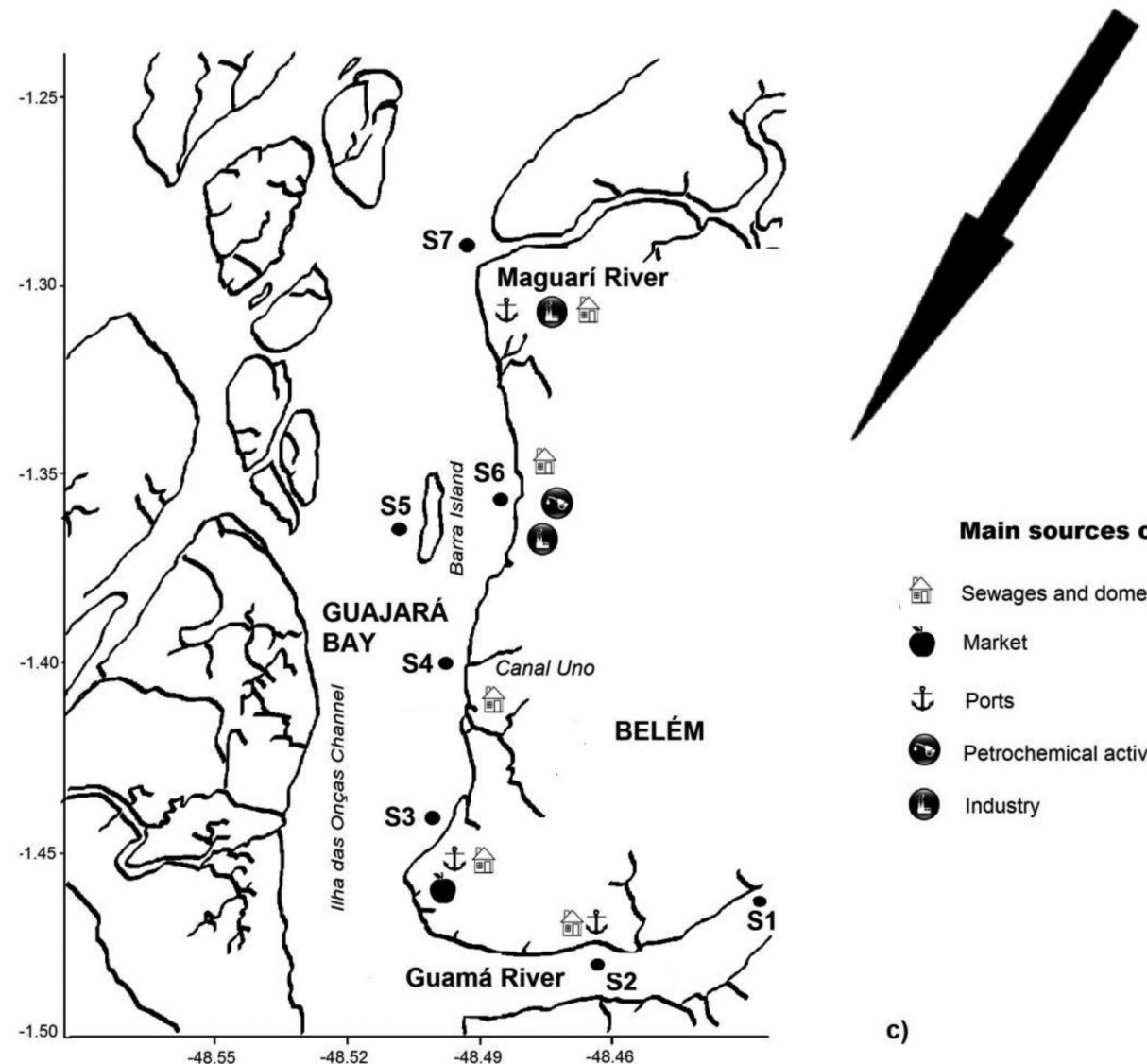

Main sources of pollution

酳 Sewages and domestic wastes

Market

$\downarrow$ Ports

(3) Petrochemical activity

(1) Industry

c)

Figure 1. a) South America, Brazil and the Amazon Basin (in black); b) The Amazon basin in Brazil, with the main tributaries and State capital cities; c) Location of the seven sampling stations (S1 to S7) and pollution sources in Guajará Bay.

conducting the analysis. Larval spatial distribution was investigated through a complete linkage analysis using the Bray Curtis Similarity Measure. The Similarity Percentages test (SIMPER) was run to determine the contribution of each larval group to the average BrayCurtis dissimilarity index, following a 75\% similarity cut. Shannon's diversity index (H') and Pielou's equitability index $(\mathrm{J})$ were used on spatio-temporal data. The BIOENV routine based on the Spearman rank correlation analysis was run to assess environmental variables that best explained communities' pattern during the study period. The above mentioned analyses and indices calculation were performed using the routine of the Plymouth Routine Multivariate Ecological Research - PRIMER - package, version 6.0 (Clarke \& Aindworth 1993, Clarke \& Gorley 2006).
To verify the existence of an ordination between species and abiotic samples at each station, the larval density matrix was first submitted to Detrended Correspondence Analysis (DCA; Ter Braak 1988) with detrending by segments. As the gradient length was short $(<2.0)$, indicating a linear response, Redundancy Analysis (RDA) was used. The analysis was performed separately on the September and December data to assess the existence of a pattern in larval distribution. The analysis was not repeated on the March and June data as they counted very few larvae.

Cluster and RD analyses were performed only on the three most abundant families (Engraulidae, Clupeidae, Sciaenidae) with discrimination of larval development stages, resulting in a total of nine groups. Yolk-sac larvae were very few and included in the preflexion group. 


\section{Results}

A total of 4,663 fish larvae were collected, corresponding to a mean density of 132 individuals. $100 \mathrm{~m}^{-3}$. A total of nine families and eight species were identified. Those are: Clupeidae $\left(76.100 \mathrm{~m}^{-3}\right)$, Engraulidae $\left(42.100 \mathrm{~m}^{-3}\right)$, Sciaenidae - Cynoscion acoupa (Lacepède, 1801), Plagioscion squamosissimus (Heckel, 1840), Stellifer rastrifer (Jordan, 1889), Sciaenidae sp. 1, Sciaenidae sp. 2 - $\left(10.100 \mathrm{~m}^{-3}\right)$, Ariidae $\left(2.100 \mathrm{~m}^{-3}\right)$, Tetraodontidae - Colomesus psittacus (Bloch \& Schneider, 1801) - $\left(0.3 .100 \mathrm{~m}^{-3}\right)$, Achiriidae - Achirus lineatus (Linnaeus, 1758) - $\left(0.3 .100 \mathrm{~m}^{-3}\right)$, Hemiramphidae - Hyporhamphus roberti (Valenciennes, 1847) - $\left(0.3 .100 \mathrm{~m}^{-3}\right)$, Syngnathidae - Oostethus lineatus (Kaup, 1856) - $\left(0.1 .100 \mathrm{~m}^{-3}\right)$ and Carangidae - Oligoplites palometa (Cuvier, 1833) - $\left(0.02 .100 \mathrm{~m}^{-3}\right)$. The values in brackets indicate the overall family mean density $\left(.100 \mathrm{~m}^{-3}\right)$. Among these nine families, only engraulids, clupeids and sciaenids were encountered at all cruises (Table 1). All three families presented individuals at all development stages. The non-identified larvae counted for $1.8 \%$ of the total population.

Table 1. Larval density $\left(.100 \mathrm{~m}^{-3}\right)$ discriminating family, development stage and season. For clarity purpose, decimals were mentioned only for values $<1$. Pre- $\mathrm{F}=$ Pre-flexion stage, $\mathrm{F}=$ flexion stage, Pos- $\mathrm{F}=$ post-flexion stage; $\mathrm{D} / \mathrm{W}, \mathrm{W}, \mathrm{W} / \mathrm{D}$ and $\mathrm{D}=$ dry/wet, wet, wet/dry and dry seasons, respectively.

\begin{tabular}{|c|c|c|c|c|c|}
\hline \multirow[t]{2}{*}{ Family } & \multirow{2}{*}{$\begin{array}{c}\text { Development } \\
\text { stage }\end{array}$} & \multicolumn{4}{|c|}{ Density $\left(.100 \mathrm{~m}^{-3}\right)$} \\
\hline & & $\mathbf{D} / \mathbf{W}$ & $\mathbf{W}$ & W/D & D \\
\hline \multirow[t]{4}{*}{ Clupeidae } & Pre-F & 89 & 15 & 10 & 89 \\
\hline & $\mathrm{F}$ & 30 & 5 & 4 & 27 \\
\hline & Pos-F & 15 & 4 & 3 & 13 \\
\hline & Total & 134 & 24 & 17 & 129 \\
\hline \multirow[t]{4}{*}{ Engraulidae } & Pre-F & 69 & 2 & 0.4 & 8 \\
\hline & $\mathrm{F}$ & 13 & 4 & 2 & 9 \\
\hline & Pos-F & 10 & 9 & 4 & 39 \\
\hline & Total & 92 & 15 & 6.4 & 56 \\
\hline \multirow[t]{2}{*}{ Carangidae } & Pos-F & & 0.1 & & \\
\hline & Total & & 0.1 & & \\
\hline \multirow[t]{4}{*}{ Sciaenidae } & Pre-F & 16 & 0.2 & 3 & 16 \\
\hline & $\mathrm{F}$ & 1 & & & 1 \\
\hline & Pos-F & 0.2 & & 0.1 & 4 \\
\hline & Total & 17.2 & 0.2 & 3.1 & 21 \\
\hline \multirow[t]{2}{*}{ Hemiramphidae } & Pos-F & & 0.1 & & 1 \\
\hline & Total & & 0.1 & & 1 \\
\hline \multirow[t]{4}{*}{ Tetraodontidae } & Pre-F & 0.1 & & & 0.5 \\
\hline & $\mathrm{F}$ & 0.1 & & & \\
\hline & Pos-F & & 0.1 & & 0.4 \\
\hline & Total & 0.2 & 0.1 & & 0.9 \\
\hline \multirow[t]{4}{*}{ Ariidae } & Pre-F & & & & 0.5 \\
\hline & $\mathrm{F}$ & & & 0.1 & 4 \\
\hline & Pos-F & & & & 3 \\
\hline & Total & & & 0.1 & 7.5 \\
\hline \multirow[t]{4}{*}{ Achiriidae } & Pre-F & 0.1 & & & \\
\hline & $\mathrm{F}$ & & & & \\
\hline & Pos-F & 0.2 & & & 1 \\
\hline & Total & 0.3 & & & 1 \\
\hline \multirow[t]{2}{*}{ Syngnathidae } & Pos-F & 0.1 & & & 0.3 \\
\hline & Total & 0.1 & & & 0.3 \\
\hline \multirow[t]{4}{*}{ Entire population } & Pre-F & 174 & 17 & 14 & 114 \\
\hline & $\mathrm{F}$ & 44 & 9 & 6 & 41 \\
\hline & Pos-F & 26 & 13 & 7 & 62 \\
\hline & Total density & 244 & 39 & 27 & 217 \\
\hline
\end{tabular}

The Wet and W/D seasons presented low densities, averaging $33.100 \mathrm{~m}^{-3}$, while the Dry and D/W seasons showed values about eight times higher (Table 1). ANOSIM (global $\mathrm{R}=0.343$ ) indicated no differences between larval assemblages during the Wet and W/D seasons and during the Dry and D/W seasons. All other combinations were statistically different. The rainy season was characterized by a predominance of pre-flexion larvae while the opposite was observed during the Dryer period (Table 1). Equitability and diversity were highest during the $\mathrm{W} / \mathrm{D}$ season $\left(\mathrm{H}^{\prime}=1,26 ; \mathrm{J}=0,61\right)$ and lowest during the Wet season $\left(H^{\prime}=0,78 ; \mathrm{J}=0,40\right)$.

The density-based clustering applied on density per station separated two groupings with a similarity index of $68.6 \%$ (Figure 2), one including both stations distant from the city (S1 and S5 $-88 \%$ similarity) and another one gathering the areas in direct contact with the urban area (S2, S3, S4, S6 and S7 - 80\% similarity). Within this second group, two subsets were differentiated; one comprising the two River mouth stations (S2 and S7) and a second one with all three stations scattered along the waterfront (S3, S4 and S6). The SIMPER analysis indicated that the predominance of young clupeiforms, especially engraulids, at S1 and S5, contributed more to the dissimilarity between the two main groupings. On the other hand, stations at the river mouths and city frontline were separated based on the abundance of engraulid and sciaenid post-flexion larvae. The former were more numerous along the city shoreline while the sciaenids predominated at S2 and S7.

Station S4 presented the highest equitability $\left(\mathrm{H}^{\prime}=1.36\right)$ and diversity $(\mathrm{J}=0.59)$ indices while the lowest values were obtained at $\mathrm{S} 1\left(\mathrm{H}^{\prime}=0.81 ; \mathrm{J}=0.37\right)$.

The BIOENV analysis indicated that nitrate with $\mathrm{pH}$ best explained the larval assemblage (0.6).

Physicochemical properties of water at each station are summarized in Table 2 and presented through the mean of the March, June, September and December values. Data obtained in September and December and used for the RDAs are presented separately.

The first two axes generated by the RDAs explained $88.5 \%$ of the cumulative percentage of the species-environment relation in September and $93.5 \%$ in December (Table 3). The plots of RDA samples and species scores illustrate their dispersion pattern, and the plots of environmental variables vectors illustrate the directions and strengths of environmental relationships within the first two dimensions of the RDA ordination (Figure 3). Clupeiforms prevailed at both stations located in areas free of direct human activities, S5 in September and S1 in December. In December the pre-flexion and flexion clupeid and engraulid larvae sheltered at those stations were positively correlated to the suspended matter concentrations and, to a lower extent, to the orthophosphate; in September results were similar, but with a better participation of the orthophosphate. Distribution of the older clupeiforms (especially CPo) showed no reproducibility between months. Thus, in September the larvae

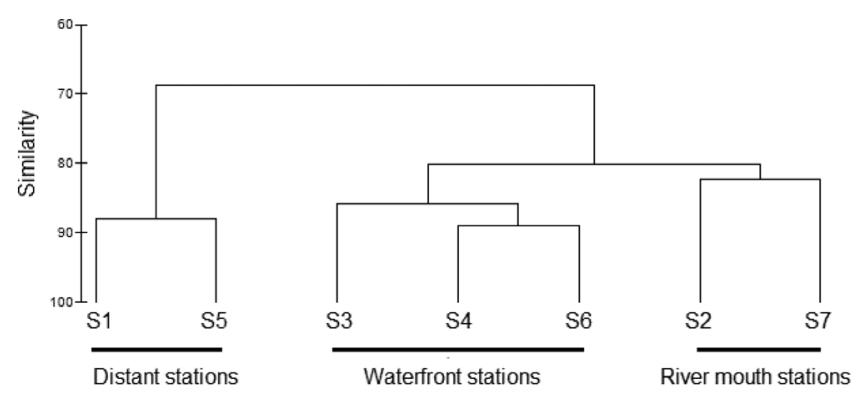

Figure 2. Cluster analysis showing the spatial repartition of all seven stations based on the densities of nine larval groups. 
Fish larvae in a North Brazilian estuary

Table 2. Temporal mean and standard deviation of water parameters data by station. September and December data are mentioned separately. $\mathrm{T}=$ temperature $\left({ }^{\circ} \mathrm{C}\right), \mathrm{Cnd}=$ conductivity $\left(\mu \mathrm{S} . \mathrm{cm}^{-1}\right), \mathrm{Tb}=$ turbidity $(\mathrm{NTU}), \mathrm{MS}=$ suspended particulate matters $\left(\mathrm{mg} \cdot \mathrm{l}^{-1}\right), \mathrm{COD}=$ chemical oxygen demand $\left(\mathrm{mg} . \mathrm{l}^{-1}\right), \mathrm{Nta}=$ nitrate $\left(\mathrm{mg} \cdot \mathrm{l}^{-1}\right)$, Ama $=$ ammonia $\left(\mathrm{mg} \cdot \mathrm{l}^{-1}\right)$ and $\mathrm{OP}=$ orthophosphate $\left(\mathrm{mg} \cdot \mathrm{l}^{-1}\right)$.

\begin{tabular}{|c|c|c|c|c|c|c|c|}
\hline & \multicolumn{7}{|c|}{$\begin{array}{l}\text { ANNUAL MEAN } \pm \text { SD } \\
\text { September / December }\end{array}$} \\
\hline & S1 & S2 & S3 & S4 & S5 & S6 & S7 \\
\hline \multirow{2}{*}{$\mathbf{T}$} & $31.8 \pm 1.0$ & $32.5 \pm 2.4$ & $31.3 \pm 0.5$ & $31.5 \pm 0.6$ & $31.3 \pm 0.5$ & $31.6 \pm 1.1$ & $31.4 \pm 0.7$ \\
\hline & $31 / 31$ & $32 / 31$ & $31 / 31$ & $31 / 31$ & $32 / 31$ & $31 / 31$ & $31 / 31$ \\
\hline pH & $5.9 \pm 0.3$ & $6.4 \pm 0.4$ & $6.1 \pm 0.5$ & $5.9 \pm 0.4$ & $5.5 \pm 0.3$ & $5.8 \pm 0.5$ & $5.8 \pm 0.4$ \\
\hline \multirow{3}{*}{ Cnd } & $6.1 / 5.9$ & $6.7 / 6.6$ & $6.2 / 6.3$ & $6.4 / 6.0$ & $5.7 / 5.8$ & $6.4 / 6.0$ & $6.4 / 5.9$ \\
\hline & $177.3 \pm 175$ & $427.0 \pm 716$ & $267.3 \pm 397$ & $189.3 \pm 241$ & $98.3 \pm 126$ & $174.6 \pm 233$ & $130.9 \pm 208$ \\
\hline & $243 / 395$ & $140 / 1498$ & $152 / 856$ & $132 / 544$ & $56 / 286$ & $132 / 515$ & $13 / 442$ \\
\hline \multirow{2}{*}{ Turb } & $42.8 \pm 30$ & $29.8 \pm 23$ & $35.8 \pm 20$ & $40.1 \pm 21$ & $50.6 \pm 22$ & $44.6 \pm 17$ & $50.9 \pm 27$ \\
\hline & $34 / 25$ & $21 / 22$ & $20 / 40$ & $38 / 30$ & $41 / 46$ & $50 / 37$ & $39 / 47$ \\
\hline \multirow{2}{*}{ MS } & $34.1 \pm 32$ & $17.5 \pm 12$ & $26.2 \pm 17$ & $22.3 \pm 17$ & $36.9 \pm 33$ & $16.1 \pm 20$ & $28.2 \pm 35$ \\
\hline & $39 / 12$ & $23 / 3$ & $39 / 4$ & $37 / 4$ & $39 / 4$ & $45 / 3$ & $77 / 2$ \\
\hline \multirow{2}{*}{ COD } & $13.1 \pm 4.9$ & $11.5 \pm 9.1$ & $15.7 \pm 9.0$ & $15.2 \pm 8.0$ & $19.7 \pm 4.5$ & $17.6 \pm 7.3$ & $26.3 \pm 12.3$ \\
\hline & $17 / 9$ & $1 / 8$ & $8 / 28$ & $25 / 9$ & $17 / 18$ & $17 / 18$ & $34 / 28$ \\
\hline \multirow{2}{*}{ NTa } & $0.68 \pm 0.13$ & $0.70 \pm 0.34$ & $0.98 \pm 0.25$ & $1.00 \pm 0.22$ & $0.95 \pm 1.03$ & $1.10 \pm 0.27$ & $2.08 \pm 1.58$ \\
\hline & $0.5 / 0.7$ & $0.3 / 0.6$ & $0.7 / 0.9$ & $0.8 / 1.0$ & $0.1 / 1.2$ & 1.5/1.0 & 1.3/0.9 \\
\hline \multirow{2}{*}{ Ama } & $0.10 \pm 0.08$ & $0.24 \pm 0.05$ & $0.12 \pm 0.28$ & $0.36 \pm 0.23$ & $0.09 \pm 0.13$ & $0.20 \pm 0.18$ & $0.27 \pm 0.33$ \\
\hline & $0.1 / 0.1$ & $0.3 / 0.2$ & $0.2 / 0.5$ & $0.6 / 0.7$ & $0 / 0.31$ & $0.24 / 0.6$ & $0.23 / 0.5$ \\
\hline \multirow{2}{*}{ OP } & $0.05 \pm 0.03$ & $0.02 \pm 0.02$ & $0.04 \pm 0.03$ & $0.04 \pm 0.04$ & $0.08 \pm 0.07$ & $0.06 \pm 0.03$ & $0.05 \pm 0.03$ \\
\hline & $0.01 / 0.05$ & $0.01 / 0.01$ & $0.06 / 0.01$ & $0.01 / 0.09$ & $0.03 / 0.16$ & $0.02 / 0.06$ & $0.02 / 0.04$ \\
\hline
\end{tabular}

Table 3. a) Results from Redundancy Analysis of the nine larval groups captured in September and December of 2005 in Guajará Bay; b) Intraset correlations of water quality parameters on the two first axes of the RDA for the months of September and December 2005.

\begin{tabular}{|c|c|c|c|c|}
\hline RDA & \multicolumn{4}{|c|}{ AXES } \\
\hline SEPTEMBER & 1 & 2 & 3 & 4 \\
\hline Eigenvalues & 0.674 & 0.211 & 0.065 & 0.028 \\
\hline $\begin{array}{l}\text { Cumulative percentage variance of } \\
\text { species-environment relation }\end{array}$ & 67.4 & 88.5 & 95.1 & 97.9 \\
\hline Sum of all eigenvalues & \multirow{2}{*}{\multicolumn{4}{|c|}{1.000}} \\
\hline DECEMBER & & & & \\
\hline Eigenvalues & 0.839 & 0.097 & 0.051 & 0.009 \\
\hline $\begin{array}{l}\text { Cumulative percentage variance of } \\
\text { species-environment relation }\end{array}$ & 83.9 & 93.5 & 98.6 & 99.5 \\
\hline \multirow{3}{*}{$\begin{array}{l}\text { Sum of all eigenvalues } \\
\text { b) }\end{array}$} & \multicolumn{4}{|c|}{1.000} \\
\hline & \multicolumn{2}{|c|}{ SEPTEMBER } & \multicolumn{2}{|c|}{ DECEMBER } \\
\hline & Axis 1 & Axis 2 & Axis 1 & Axis 2 \\
\hline $\mathrm{pH}$ & -0.5359 & 0.5451 & -0.7670 & -0.0751 \\
\hline Cnd & -0.4940 & 0.6182 & -0.5799 & 0.2869 \\
\hline $\mathrm{Tb}$ & -0.1429 & -0.8080 & 0.2666 & 0.3136 \\
\hline MS & 0.7961 & 0.1986 & 0.1431 & -0.2991 \\
\hline COD & -0.5114 & -0.2463 & 0.0877 & -0.1185 \\
\hline Nta & -0.0604 & -0.8386 & -0.2992 & 0.3335 \\
\hline Ama & -0.7288 & -0.3275 & -0.2555 & 0.2669 \\
\hline $\mathrm{OP}$ & 0.3862 & -0.6127 & 0.4603 & 0.3010 \\
\hline
\end{tabular}

were present all along the city frontline and positively correlated to the nutrient concentrations, while in December they were found predominantly in the Guamá River and at S6, near the Maguarí River, where nutrients were less.

Pre-flexion and flexion sciaenid larvae were found mostly along the city frontline, especially at S3 and S4. Both in September and December their presence was best explained by the orthophosphate concentrations. The post-flexion individuals were more numerous at the Guamá and Maguarí Rivers without any special affinities towards the water parameters assessed.

\section{Discussion}

Oligohaline areas are important nursery grounds for both estuarine and freshwater fishes although they are often characterized by fish assemblages of low diversity (Rozas \& Hackney 1984, Campfield \& Houde 2011). Such is the case of Guajará Bay. Densities and diversity registered in this study are considered average to low compared to those in the lower estuary and freshwaters of the Amazon basin (Araújo-Lima et al. 2001, Costa et al. 2011). Clupeiforms strongly dominated the assemblages, as it is the case in many Brazilian and 
Sarpedonti V. et al.
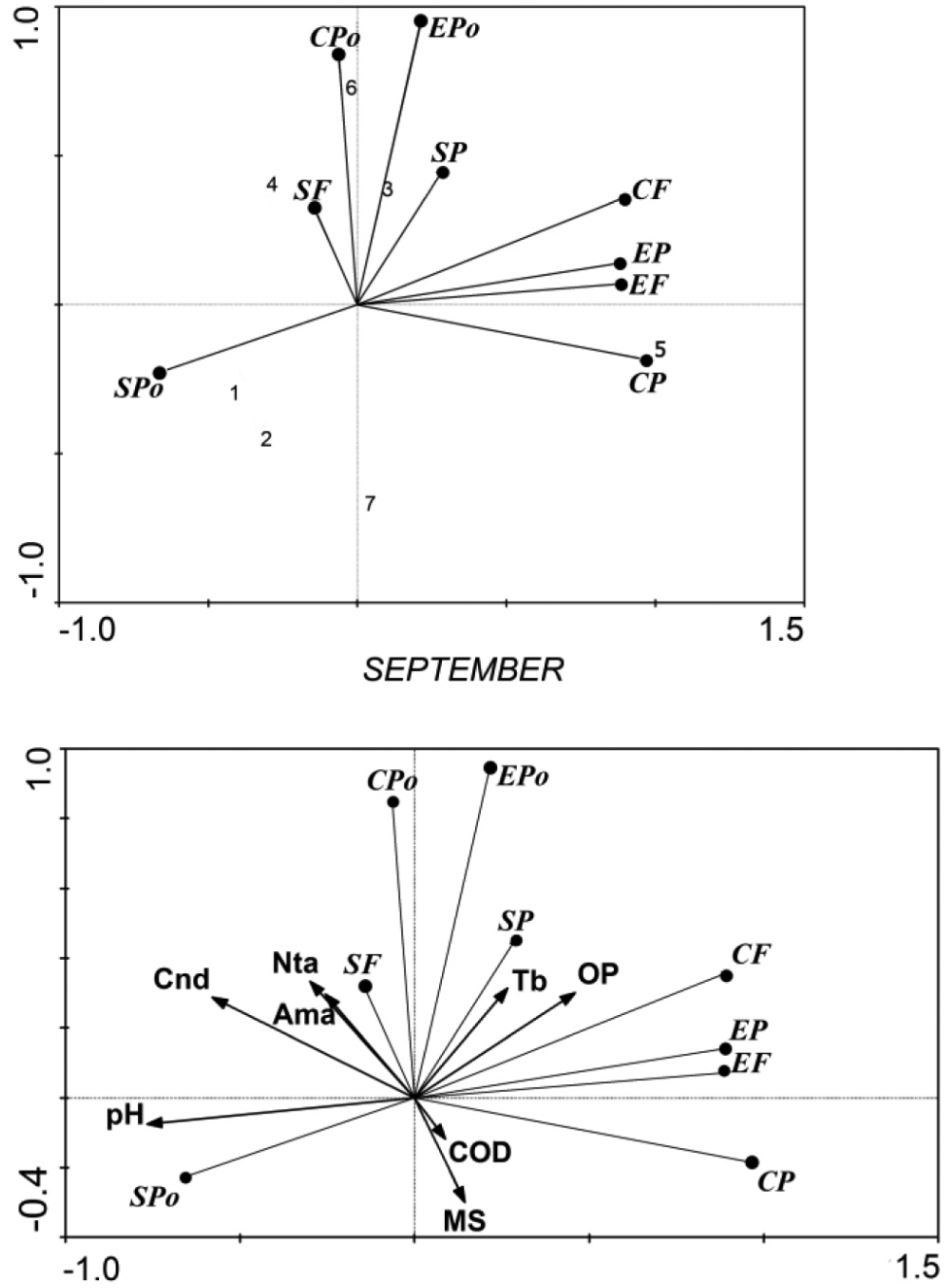
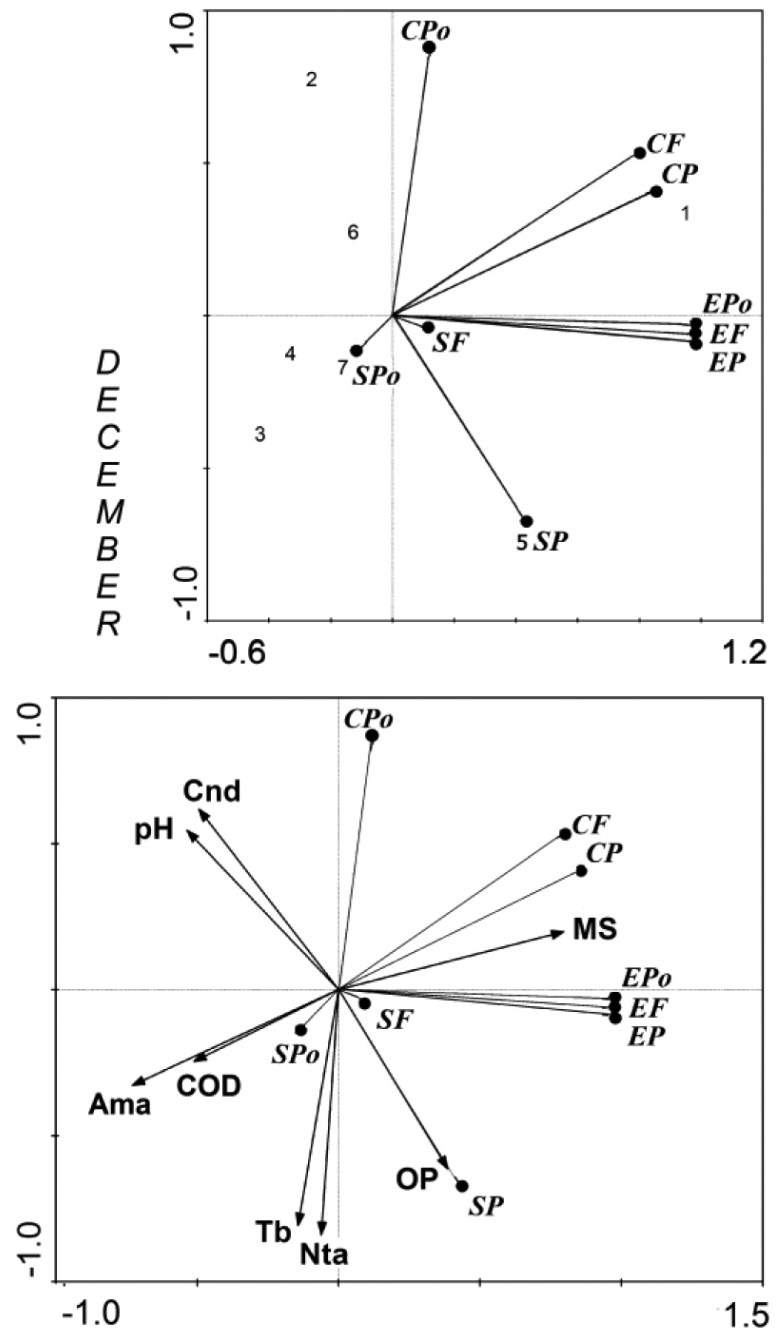

Figure 3. Ordination diagram of the Redundancy Analysis of water parameters and fish larvae in Guajará Bay showing the sampling stations in September and December of 2005. EP, EF, EPo = engraulids in pre-flexion, flexion and post-flexion; CP, CF, CPo = clupeids in pre-flexion, flexion and post-flexion; SP, $\mathrm{SF}, \mathrm{SPo}=$ sciaenids in pre-flexion, flexion and post-flexion. $\mathrm{Cnd}=$ conductivity, $\mathrm{Tb}=$ turbidity, $\mathrm{MS}=$ suspended matter, $\mathrm{COD}=$ chemical oxygen demand, $\mathrm{Nta}=$ nitrate, $\mathrm{Ama}=$ ammonia and $\mathrm{OP}=$ orthophosphate.

worldwide estuaries (Barletta-Bergan et al. 2002a, Bonecker et al. 2007). Studies on the adults' gonad maturation stages indicated that the widely distributed euryhaline engraulid Anchoa spinifer (Valenciennes, 1848) predominantly used Guajará Bay as a breeding ground (Viana et al. 2010). However, difficulties faced to identify clupeiform larvae up to the species level as it is often the case (e.g. Coser et al. 2007), did not allow cross-checking this information with the ichthyoplanktonic data. The absence of Pristigasteridae larvae contrasted with the relatively strong abundance of the adults individuals (Viana et al. 2010), suggesting that their main spawning ground is not in the area of study. It is however noted that a few larvae of this family were encountered in small, highly contaminated creeks of the capital city during the months of September and January (V. Sarpedonti, unpublished data).

Discrepancies between adults (Viana et al. 2010) and larvae (this study) encounters in the bay were also registered among nonclupeiforms and attributed to habitat specificity or reproduction strategy. For example, adults Colomesus asellus (Müller \& Troschel, 1849 - Tetraodontidae) and Curimata inornata (Vari, 1989 - Curimatidae) used the bay as a breeding ground; however, as they occupy essentially small channels, their larvae were absent from the bay samples (this study) but were found in nearby mangrove environments (Sarpedonti et al. 2008) and small creeks of Belém's Islands (V. Sarpedonti, unpublished data). The practice of parental care, as it is the case for Anableps anableps (Linnaeus, 1758 -Anablepidae) and Hoplia gr. malabaricus (Bloch, 1794 - Erythrinidae), justify the scarcity of their larvae in the planktonic catches (Prado et al. 2006, Oliveira et al. 2011). The opposite scenario, when only larvae were present, was also observed. This was the case of the sciaenid Stellifer rastrifer. According to Camargo \& Isaac (2005) the adults' spawning ground is located in the lower estuary; yet, eggs and newly hatched larvae would not remain there but drift towards the upper estuary where salinity is much lower. Similar behaviour applies to Cynoscion acoupa (Barletta \& Barletta-Bergan 2009), although the presence of their larvae in oligohaline waters like in Guajará Bay, is unusual. Plagioscion squamosissimus is the only identified sciaenid species that use Guajará Bay both at the larval and adult stage. This pelagic species, originally from the Amazonian basin, is commonly found in the freshwaters of Northern South America. The relative abundance of young larvae and concentration of the elderly at the river mouth corroborated the migration pattern documented for this species. Indeed, studies conducted in South Brazil indicated that 
adults spawn in calm areas where the young larvae would remain. As they reach a more advanced development stage, the individuals move towards areas of stronger water flow and use the currents to reach other nursery grounds (Baumgartner et al. 2003, Bialetzki et al. 2004). All the remaining larval species that were absent from the juvenile/adult catches (Viana et al. 2010) counted very few individuals suggesting that their presence was accidental or that Guajará Bay was on their migration route.

The time frame for fish reproduction in tropical countries matches either a peak in natural food production (Cushing 1990) or propitious weather conditions that enhance recruitment success (Sinclair \& Tremblay 1984). The main reproduction period at the onset of the rainy season (Viana et al. 2010, present study) when levels of primary production are high (Paiva et al. 2006), supports the first affirmation. According to Paiva et al. (2006), the high quantity of sediment load transported by the Guamá River during the rainy season increases water turbidity which, in return, inhibits phytoplankton growth. On the contrary, the greater water transparency during the dry season favours primary production and therefore larval survival through an increase of aliments availability (Cushing 1990, Mertz \& Myers 1994). Besides food availability, floodplains that form with rising water level are crucial to the survival of many species that use these temporary environments as nursery grounds (Sousa \& Freitas 2008, Sarpedonti et al. 2008, Barletta-Bergan et al. 2002b).

Fish larvae distribution is highly variable and depends essentially on hydrogeographical processes and meteorological events (Munk et al. 2003). The RDAs conducted on the September and December data showed similar patterns of larval distribution, indicating constancy in the use of Guajará Bay. For both months, assemblages' structure was controlled by the interactions between larval biological characteristics at the ontogenetic and taxonomic levels, and water components. Segregation between development stages is usually explained by a gain, or change, in biological abilities that enables the older larvae to use a wider - or new - range of environments (Simonović et al. 1999, Sarpedonti et al. 2000, Pinder et al. 2005). In this study growing Clupeiforms moved from the farmost stations, $\mathrm{S} 1$ and $\mathrm{S} 5$, to the stations closer to the waterfront. The higher levels of conductivity and concentrations of N-compounds at stations S3, S4, S6 and S7 were related to the organic matter and domestic wastes poured into the bay. It is suggested that the higher concentrations of $\mathrm{NO}_{3}$ (compatible with the ichthyoplankton life) in a stretch where currents are weaker (Barros et al. 2011) contributed to the higher larval diversity and to the approximation to the city of post-flexion clupeiforms. Ammonia levels of toxicity for fish vary considerably with $\mathrm{pH}$, temperature, dissolved oxygen, taxa and development stages (Vosylienë \& Kazlauskienë 2004, Eddy 2005). Previous studies indicated that concentrations registered at station S4 both in September and December can be unsuitable for the younger stages of some species. However, it was not possible to verify whether this observation also applied to the species present in the bay, although a negative correlation between young clupeiforms and $\mathrm{NH}_{3}$ was observed, corroborating the findings of Mafalda Junior et al. (2008). Orthophosphate ions correspond to the aqueous form of phosphates; they are readily used by plants, or stored when present in excess. Their level of concentration is crucial for the ecosystem, especially freshwater environments where eutrophication is essentially controlled by P and not N (Howarth et al. 2000). Unlike nitrate, the higher amounts of OP were not necessarily associated to the waterfront stations and city pollution. Both $\mathrm{N}$ and $\mathrm{P}$ are directly related to sewage pouring; however $\mathrm{P}$ is also highly correlated to agricultural activities and erosion in the watershed. Phosphate concentrations loaded by the Guamá and Maguarí Rivers along their courses are high; once in the bay, particles are dispersed by the strong currents to form peaks of concentration randomly distributed in the bay. The amounts of OP registered occasionally indicated quantities that could affect the environment through eutrophication. However, these cases were rare and taking into consideration the continuous mixing of waters in the bay, it is believed that, at the time of the study, concentrations were harmless to fish larvae.

The remaining water parameters, temperature, suspended matter and $\mathrm{pH}$ were within ranges of compatibility for aquatic life (www. mma.gov.br/conama/; www.water.epa.gov, http://ceqg-rcqe.ccme. $\mathrm{ca} /)$. It is noted that the occasional peaks ( $>500 \mathrm{NTU})$ of turbidity were related to the rainy season when water flow increases drastically. The $\mathrm{pH}$, slightly acid in reason of the high concentrations of humic acid in the soil, is within range of normality for the Amazon Basin and should not be a limiting factor for larval growth and survival.

Although this study associated some larval distribution patterns to water parameters, it is unlikely that water quality governs larval assemblage. The water showed signs of contamination but, in the overall, parameters remained within the ranges of tolerance for fish. However, as little is known about larvae tolerance to water quality, histological analysis were subsequently performed on tissues of 28 clupeiforms measuring $1.0 \mathrm{~mm}$ total length. Their digestive tract cells showed no alterations sustaining the hypothesis that, to date, the environment is suitable for the ichthyoplankton. Complementary analysis on water microbiology indicated intensive amounts of bacteria, essentially coliforms, which make the environment inappropriate for Human use (Dilva 2006). However, their impact on the fish community of the Bay of Guajará is yet to be demonstrated. Instead, it is more probable that the hydrodynamic features around the insular system controls larval distribution.

\section{Acknowledgements}

The authors would like to thank Dr. José Souto Rosa Filho for his valuable assistance throughout the project, and all students and lab members who helped during field collections and lab work. This project was financed by the Secretary of Environment, Pará State, Brazil (SECTAM-PA) and the Brazilian National Research Centre (CNPq), process number 35.0628/2004-1.

\section{References}

ARAÚJO-LIMA, C.A.R.M., SILVA DA, V.V., PETRY, P. \& MOURA, S.M.L. 2001. Diel variation of larval fish abundance in the Amazon and Rio Negro. Braz. J. Biol. 61(3):357-362.

BARLETTA-BERGAN, A., BARLETTA, M. \& SAINT-PAUL, U. 2002 a. Structure and seasonal dynamics of larval fish in the Caete River Estuary in North Brazil. Estuar. Coast. Shelf Sci. 54:193-206.

BARLETTA-BERGAN, A., BARLETTA, M. \& SAINT-PAUL, U. 2002b. Community structure and temporal variability of ichthyoplankton in North Brazilian mangrove creeks. J. Fish Biol. 61(A):33-51.

BARLETTA, M. \& BARLETTA-BERGAN, A. 2009. Endogenous Activity Rhythms of Larval Fish Assemblages in a Mangrove fringed Estuary in North Brazil. Open Fish Sci. J. 2:15-24. http://dx.doi. org/10.2174/1874401X00902010015

BARROS, M.L.C., SANTOS SENA, M.J. S., MESQUITA, A.L.A., BLANCO, C.J.C. \& SECRETAN, Y. 2011. A water flow pattern analysis of Guajará Bay-Amazon estuary - Brazil. J. Braz. Soc. Mech. Sci. Eng. 33(1):79-85.

BEZERRA, M.O., MEDEIROS, C., KRELLING, A.P.M., ROSÁRIO, R.P. \& ROLLNIC, M. 2011. Physical oceanographic behavior at the Guama/ Acara-moju and the Paracauari River mouths, Amazon Coast (Brazil). J. Coast. Res. 64:1448-1452.

BAUMGARTNER, M.S.T., NAKATANI, K., BAUMGARTNER, G. \& MAKRAKIS, M.C. 2003. Spatial and temporal distribution of "curvina" larvae (Plagioscion squamosissimus Heckel, 1840) and its relationship 
to some environmental variables in the upper Paraná River floodplain, Brazil. Braz. J. Biol. 63(3):381-391.

BIALETZKI, A., NAKATANI, K., SANCHES, P.V. \& BAUMGARTNER, G. 2004. Eggs and larvae of the 'curvina' Plagioscion squamosissimus (Heckel, 1840) (Osteichthyes, Sciaenidae) in the Baía River, Mato Grosso do Sul State, Brazil. J. Plankton Res. 26(11):1327-1336. http://dx.doi. org/10.1093/plankt/fbh123

BONECKER, A.C.T., CASTRO, M.S., NAMIKI, C., BONECKER, F. \& BARROS, T.F.B.A.G. 2007. Larval fish composition of a tropical estuary in northern Brazil (2 18'-2 47'S/044 20'-044 25'W) during the dry season. PanamJAS 2: 235-241.

CABRAL, N.M.T. 2007. Teores de nitrato $\left(\mathrm{NO}_{3}^{-}\right)$e amônio $\left(\mathrm{NH}_{4}^{+}\right)$nas águas do aqǘfero barreiras nos bairros do Reduto, Nazaré e Umarizal - Belém/ Pa. Quim. Nova 30(8):1804-1808. http://dx.doi.org/10.1590/S010040422007000800003

CAMARGO, M. \& ISAAC, V. 2005. Reproductive biology and spatiotemporal distribution of Stellifer rastrifer, Stellifer naso and Macrodon ancylodon (Sciaenidae) in the Caeté Estuary, Northern Brazil. Braz. J. Oceanogr. 53(1-2):13-21.

CAMPFIELD, P.A. \& HOUDE, E.D. 2011. Ichthyoplankton community structure and comparative trophodynamics in an estuarine transition zone. Fish. Bull. 109:1-19.

CARVALHO, G.O. 2006. Environmental resistance and the politics of energy development in the Brazilian Amazon. J. Environ. Dev. 15(3):245-268.

CLARKE, K.R. \& AINDWORTH, M. 1993. A method of linkink multivariate community structure to environmental variables. Mar. Ecol. Prog. Ser. 92:205-217. http://dx.doi.org/10.3354/meps092205

CLARKE, K.R. \& GORLEY, R.N. 2006. PRIMER v6: User Manual/Tutorial. PRIMER-E, Plymouth.

COSER, L.M., PEREIRA, B.B . \& JOYEUX, J.C. 2007. Descrição da comunidade ictioplânctonica e sua distribuição espacial no estuário dos rios Piraquê-açu e Piraquê-mirim, Aracruz, ES, Brasil. Interciencia 32(4):233-241.

COSTA, A.J.G., COSTA, K.G., PEREIRA, L.C.C., SAMPAIO, M.I. \& COSTA, R.M. 2011. Dynamics of hydrological variables and the fish larva community in an Amazonian estuary of northern Brazil. J. Coastal Res. 64:1960-1964.

COSTELLO, M.J. \& GAMBLE, J.C. 1992. Effects of sewage sludge on marine fish embryos and larvae. Mar. Environ. Res. 33(1):49-74.

COSTELLO, M.J. \& READ, P. 1994. Toxicity of Sewage Sludge to Marine Organisms: A Review. Marine Environmental Research 37:23-46. http:// dx.doi.org/10.1016/0141-1136(94)90061-2

CUSHING, D.H. 1990. Plankton production and year-class strength in fish populations: an update of the match/mismatch hypothesis. Adv. Mar. Biol. 26:249-293. http://dx.doi.org/10.1016/S0065-2881(08)60202-3

DILVA, D.F. 2006. Utilização de indicadores biológicos na avaliação da qualidade da água da Baía do Guajará e do Rio Guamá (Belém-Pará). Dissertação de mestrado, Universidade Federal do Pará, Belém.

EDDY, F.B. 2005. Ammonia in estuaries and effects on fish. J. Fish Biol. 67:1495-1513. http://dx.doi.org/10.1111/j.1095-8649.2005.00930.x

GREGÓRIO, A.M.S. \& MENDES, A.C. 2009. Characterization of Sedimentary Deposits at the Confluence of Two Tributaries of the Pará River Estuary (Guajará Bay, Amazon). Cont. Shelf Res. 29(3):609-618. http://dx.doi.org/10.1016/j.csr.2008.09.007

HOWARTh, R., ANDERSON, D., ClOERn, J., ElFring, C., HOPKINSON, C., LAPOINTE, B., MALONE, T., MARCUS, N., McGLATHERY, K., SHARPLEY, A. \& WALKER, D. 2000. Nutrient Pollution of Coastal Rivers, Bays, and Seas. Issues Ecol. 7:2-14.

MAFALDA JUNIOR, P., SOUZA, C.S. \& VELAME, M.P.B. 2008. Fish larvae assemblage of a coastal area under influence of petrochemical activities, in Todos os Santos Bay, Bahia, Brazil. Aquat. Ecosyst. Health Mgmt. 11(4):457-464.
MARANHÃO, R.A. 2011. Impactos da ocupação urbana e qualidade das águas superficiais na microbacia de Val-de-cães (Belém/PA). Caminhos Geog.12(38):176-186.

MERTZ, G. \& MYERS, A. 1994. Match/mismatch predictions of spawning duration versus recruitment variability. Fish. Oceanogr. 3(4):236-245.

MUNK, P., HANSEN, B.W., NIELSEN, T.G. \& THOMSEN, H.A. 2003. Changes in plankton and fish larvae communities across hydrographic fronts off West Greenland. J. Plankton Res. 25(7):815-830. http://dx.doi. org/10.1093/plankt/25.7.815

MORAES, B.C., COSTA, J.M.N., COSTA, A.C.L. \& COSTA, M.H. 2005. Variação espacial e temporal da precipitação no Estado do Pará. Acta Amaz. 35(2):207-214. http://dx.doi.org/10.1590/S004459672005000200010

MOSER, H.G. 1984. Ontogeny and systematics of fishes. American Society of Ichthyologists and Herpetologists, New York.

OLIVEIRA, V.A., FONTOURA, N.F. \& MONTAG, L.G.A. 2011. Reproductive characteristics and the weight-length relationship in Anableps anableps (Linnaeus, 1758) (Cyprinodontiformes: Anablepidae) from the Amazon Estuary. Neotrop. Ichthyol. 9(4):757-766. http://dx.doi. org/10.1590/S1679-62252011005000042

PAIVA, R.S., ESKINAZI-LECA, E., PASSAVANTE, J.Z.O., SILVA-CUNHA, M.G.G. \& MELO, N.F.A.C. 2006. Considerações ecológicas sobre o fitoplâncton da Baía do Guajará e foz do Rio Guamá, Pará, Brasil. Bol. Mus. Para. Emílio Goeldi 1:133-146.

PINDER, A.C., GOZLAN, R.E., BEYER, K. \& BASS, J.A.B. 2005. Ontogenetic induced shifts in the ecology of sunbleak Leucaspius delineatus during early development. J. Fish Biol. 67(B):205-217.

PRADO, C.P.A., GOMIERO, L.M. \& FROEHLICH, O. 2006. Spawning and parental care in Hoplias malabaricus (Teleostei, Characiformes, Erythrinidae) in the Southern Pantanal, Brazil. Braz. J. Biol. 66(2B):697702.

RIBEIRO, K.T. S. 2004. Água e saúde humana em Belém. CEJUP, Belém.

RIBEIRO, K.T.S. \& MARIN, R.A. 2002. A questão ambiental da água e a interface na saúde humana. In Saúde, Trabalho e Meio Ambiente. Núcleo de Altos Estudos Amazônicos (R.C. Couto, E.R. Castro \& R.A. Marin, eds.). Belém, p.147-177.

ROZAS, L.P. \& HACKNEY, C.T. 1984. Use of oligohaline marshes by fishes and macrofaunal crustaceans in North Carolina. Estuaries 7(3):213-224.

SARPEDONTI, V., PONTON, D. \& CHONG, V.C. 2000. Description and ontogeny of young Stolephorus baganensis and Thryssa kammalensis, two Engraulididae from Peninsular Malaysia. J. Fish Biol. 56:1460-1476. http://dx.doi.org/10.1111/j.1095-8649.2000.tb02157.x

SARPEDONTI, V., ANUNCIAÇÃO, E.M.S. \& NAHUM, J.I. 2008. Ichthyoplankton variations in two mangrove creeks of the Curuçá Estuary, Pará, Brazil. Ecotrópicos 21(1):1-12.

SCHULZ, U.H. \& MARTINS-JUNIOR, H. 2001. Astyanax fasciatus as bioindicator of water pollution of Rio dos Sinos, RS, Brazil. Braz. J. Biol. 61(4):615-622.

SIMONOVIĆ, P.D., GARNER, P., EASTWOOD, E.A., KOVÁČ, V. \& COPP, G.H. 1999. Correspondence between ontogenic shifts in morphology and habitat use in minnow Phoxinus phoxinus. Environ. Biol. Fish. 56:117128. http://dx.doi.org/10.1023/A:1007541915307

SINCLAIR, M. \& TREMBLAY, M.J. 1984: Timing of spawning of Atlantic Herring (Clupea harengus harengus) populations and the match-mismatch theory. Can. J. Fish. Aquat. Sci. 41:1055-1065.

SOUSA, R.G.C. \& FREITAS, C.E.C. 2008. The influence of flood pulse on fish communities of floodplain canals in the Middle Solimões River, Brazil. Neotrop. Ichthyol. 6(2):249-255.

STRAND, J., ANDERSEN, L., DAHLLO, I. \& KORSGAARD, B. 2004. Impaired larval development in broods of eelpout (Zoarces viviparus) in Danish coastal waters. Fish Physiol. Biochem. 30:37-46. http://dx.doi. org/10.1007/s10695-004-6003-7 
TER BRAAK, C. J. F. 1988. CANOCO. A Fortran program for canonical community ordination by partial, detrended, canonical analysis, principal component analysis and redundance analysis (version 2.1). Report LWA 88-02 Mathematics Group, Wageningen.

VOSYLIENË, M.Z. \& KAZLAUSKIENË, N. 2004. Comparative studies of sublethal effects of ammonia on rainbow trout (Oncorhynchus mykiss) at different stages of its development. Acta Zool. Lituanica 14(1):1648-6919.

VIANA, A.P., LUCENA FRÉDOU, F., FRÉDOU, T., TORRES, M.F. \& BORDALO, A.O. 2010. Fish fauna as an indicator of environmental quality in an urbanised region of the Amazon estuary. J. Fish Biol.
76:467-486. PMid:20666891. http://dx.doi.org/10.1111/j.10958649.2009.02487.x

VINOD, T. 2006. From inside Brazil: development in a land of contrasts. World Bank, Washington.

WALSH, C.J. 2000. Urban impacts on the ecology of receiving waters: a framework for assessment, conservation and restoration. Hydrobiologia 431:107-114. http://dx.doi.org/10.1023/A:1004029715627

WEILAND, U., RICHTER, M. \& KASPERIDUS, H.D. 2005. Environmental management and planning in urban regions - are there differences between growth and shrinkage? In Sustainable development and planning II (C.A. Brebbia \& A. Kungolos, eds.). WIT Press, University of Thessaly, Greece, p.441-450. 